\begin{tabular}{|c|c|}
\hline ANGLES & Angles \\
\hline $\begin{array}{l}\text { NEW PERSPEETUESE } \\
\text { ANELLPHINE WNRLE }\end{array}$ & New Perspectives on the Anglophone World \\
\hline & $\begin{array}{l}2 \mid 2016 \\
\text { New Approaches to the Body }\end{array}$ \\
\hline
\end{tabular}

\title{
Corpo-real: in situ
}

\section{Natacha Grimaud and Alexandre Galopin}

\section{(2) OpenEdition}

\section{Journals}

Electronic version

URL: https://journals.openedition.org/angles/1818

DOI: 10.4000/angles.1818

ISSN: 2274-2042

\section{Publisher}

Société des Anglicistes de l'Enseignement Supérieur

\section{Electronic reference}

Natacha Grimaud and Alexandre Galopin, "Corpo-real: in situ", Angles [Online], 2 | 2016, Online since 01 April 2016, connection on 11 June 2022. URL: http://journals.openedition.org/angles/1818 ; DOI: https://doi.org/10.4000/angles.1818

This text was automatically generated on 11 June 2022.

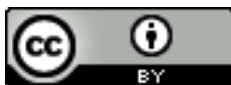

Angles est mise à disposition selon les termes de la Licence Creative Commons Attribution 4.0 International. 


\title{
Corpo-real: in situ
}

\author{
Natacha Grimaud and Alexandre Galopin
}

This media file cannot be displayed. Please refer to the online document http:// journals.openedition.org/angles/1818

\section{ABSTRACTS}

This choreographed experimentation was built around the notion of one's corporeality and how it interacts with its surroundings and the other. How are the outdoor setting's lines and outlines blend or break with that of the dancers? How do the body and nature contrast and resonate with one another, in harmony or discord, yet seemingly and continuously reaching a status quo where one does not consume the other. She and he, alone with nature, play with its rules and its rights, turning a stable yet fluid space into an extension of themselves. The two distinctive bodies in their shapes, movements and corporeal qualities end up trying to find a balance with each other while maintaining one's singular corporeality as well as one's indefectible link with space. The solo becomes a duo, and the duo becomes a trio in which spatial conceptions adjust and become one and the same for the two dancing bodies, turning space into a common place where the imperceptible becomes palpable: a catalyst through which harmonious togetherness can be found and fulfilled.

Cette expérimentation chorégraphique s'est construite autour de la notion de corporalité et de la façon dont cette dernière interagit avec son environnement et autrui. Par quels procédés les lignes et contours du décors extérieur s'entremêlent ou contrastent avec le corps des danseurs? Comment est-ce que corps et nature se dissocient et résonnent l'un dans l'autre, tantôt harmonie, tantôt dissonance, objets mouvants qui entrent en jeu pour toujours osciller avec un status quo où l'un ne se laisse pas engloutir par l'autre, où l'un existe non pas par rapport mais avec l'autre. Elle et lui, seuls avec la nature, jouent avec ses règles et ses droits, transformant un 
espace à la fois solide et fluide en une extension d'eux-mêmes. Les deux corps distinctifs aussi bien dans leurs caractéristiques, leurs silhouettes, que dans leurs qualités de mouvements et corporelles finissent par se toucher, par s'aborder autour d'un instant d'équilibre où se rencontre la corporéité de chacun tout en y intégrant le lien intime que ces corps entretiennent avec leur espace. Le solo devient duo, et le duo devient trio, moment où les conceptions spatiales se jaugent et s'ajustent pour finalement se superposer. C'est dans cet état d'unisson de ces deux corps dansants, faisant de l'espace un lieu commun où l'imperceptible devient peu à peu palpable, que s'entraperçoit le catalyseur corporéel au travers duquel la communion des entités se ressent et se parachève.

\section{INDEX}

Mots-clés: corps, danse, corporalité, nature, corporéité, environnement

Keywords: body, dance, choreography, nature, corporeality, environment

\section{AUTHORS}

\section{NATACHA GRIMAUD}

Natacha Grimaud started to study dance at the Paris' Opera in 1987 before graduating from the Rosella Hightower School of Dance in Cannes in 1994. She then worked with different ballets including the ones of Nice and Karlsruhe before integrating the Ballet du Nord with Maryse Delente in 1996. There she also collaborated on plays with Nils Christie, Paul Taylor or JeanClaude Gallotta. She left the ballet in 2002 to join the Ballet Preljocaj where she has been a pivotal dancer of the company until 2015.

\section{ALEXANDRE GALOPIN}

Alexandre Galopin graduated from the Conservatoire National Supérieur de Musique et Danse of Paris in 2005, and has, ever since, been working for numerous choreographers. He first worked with Abou Lagraa in Cutting Flat and then for Dorianne Larcher before joining the Ballet Preljocaj in 2006 where he danced for 3 years. He left in 2009 and has worked, notably, with choreographers such as David Drouard, Marco Becherini, Christian Bourigault, François LarocheValière and Jean-Claude Gallotta with whom he collaborated for the past 3 years on Daphnis é Chloé and The Rite of Spring. 